\title{
Exploration of Network-based English Teaching Mode from the Perspective of Constructivism
}

\author{
Zujun Chen ${ }^{\mathrm{a}}$ \\ Xi'an Peihua University, Shaanxi 710000, China \\ a37092309@qq.com
}

Keywords: constructivism, network, English teaching.

Abstract. With the development of network technology, Network-based English teaching is
attracting more and more attention. Under the guidance of constructivism learning theory, many
kinds of teaching methods are integrated into the teaching of College English, and the teaching ideas
of building their own knowledge system are achieved through a variety of classroom teaching modes.

\section{Introduction}

With the development of information technology and the popularization of Internet, the teaching mode of College English has changed greatly. The traditional teaching mode is facing great challenges brought by network resources, and it also faces great opportunities. In the traditional teaching, students lack the real environment of language. In modern English, teachers can provide the students with the simulated real situation from the constructivism perspective, and the new teaching model can be constructed by using the network.

\section{Theoretical Background}

The constructivism theory was put forward by the famous Swiss psychologist Piaget in 1930s. Bruner, the advocate of the cognitive revolution in 1950s, further developed the theory of constructivism. "Learning is a positive process, and the learners build up the new ideas and concepts based on their present and past knowledge in this process Learning gives learner the chance to construct knowledge on what they have learned." Under the impetus of modern educational reform, constructivism theory has been widely recognized. The modern constructivism teaching method emphasizes learners' active participation and emphasizes collaborative learning. It should teach students in accordance with their aptitude and provide personalized services for students' learning. With the popularity of the Internet and the development of computer technology, various activities carried out by using the Internet, and multiple choices are provided learners with.

The interaction theory of constructivism holds that knowledge is not acquired by imparting knowledge, but rather constructed by individuals in the interaction process of environment. The process of teaching is a process from a controlled beginning to an automatic internalization. It is a process from explicit to recessive. The key role of the process is to create a learning environment that contributes to the construction of meaning, to promote the generation of interactive behavior in social situation, and to construct knowledge based on interactive experience.

The theory of Constructivism emphasizes the importance of situation to the construction of meaning. The best situation of learning should not be simple and abstract. On the contrary, only in the real world can learning become more effective. The purpose of learning is not only to let the students understand certain knowledge, but to make the students use it and learn to solve the problem in the real world.

The interactive teaching model of College English put emphasis on its network basis and its interactive mechanism. It aims to create a network environment which is conducive to the meaning construction of the students' content, and to promote the cooperation and communication between students and between students and computer in the process of learning, so that students can form their 
own cognitive structure of the learning content. It emphasizes student-centered design of teaching process, and teachers guide students to explore, discover and link.

\section{Network-based English Teaching Model}

According to constructivism theory, students, as the main construction body of knowledge and ability, the subjectivity is not given by the teacher's kindness, but nature. The acquisition of knowledge and the construction of meaning are not taught by the teacher but are realized with the help of a specific social and cultural background with the help of teachers and learning partners.

The new constructivism learning theory encourages students to acquire information and knowledge through the Internet and integrate them with face-to-face learning communication. In other words, students should encourage students to study independently around a certain open theme through the network; in class, students should share their own learning, cooperate and explore; after class, they continue to cooperate and inquiry learning with the help of the network.

\subsection{Make Use of Network for Micro-Class Learning Before Class}

As the traditional form of basic education is complemented by the Internet, it also brings about the change of personalized learning and teaching process, which is the most important change brought by the Internet. For the knowledge of different disciplines, the micro-class can better meet the students' individualized learning, and students can choose their own learning independently and strengthen knowledge. It is an extension and an important supplement of the traditional classroom learning. On the one hand, online micro-class learning can cultivate students' self-learning ability. Students can study a specific language point repeatedly through micro-class. On the other hand, students can strengthen and consolidate the weak points at any time and anywhere according to their own needs. Students are free to watch the micro-class before class and discuss and solve problems in class. It realized the need of learning before teaching and meets the needs of students' personalized learning.

When teachers use micro-class, at the same time, they can also use some pre-class learning materials before class. For example, teachers can give students some power-points and word documents which contains related resources, such as the explanation of word phrases, the expansion of knowledge points, and the expansion of the cultural background. The teacher's micro-class combined with some text or electronic data will enable students to learn while taking notes. From the three aspects of hearing, vision, touch and sense, we can do the preview work before class to full extent. Students should truly do pre-class learning, question and discuss in class, and review after class. The construction of knowledge is based on its own acceptable progress, which is in line with students' real psychological needs.

\subsection{Teacher Optimizes the Classroom Teaching Mode in Class.}

Teachers can make use of network services in classroom teaching. In class, we should make full use of multimedia technology to enrich the presentation of audio, video, pictures, words, etc. Students can also participate in lectures and exhibitions on some classroom contents. According to the theme of the text, students can use computer, PPT to express our views, show ourselves and build confidence. In order to cultivate students' ability to use English, teachers should make use of the Internet to download the listening materials related to the curriculum in advance and develop the interactive and cooperative learning in the constructivism scaffolding teaching idea.

The interaction between teachers and students is to change the traditional teacher-oriented teaching mode, and adopt the students-oriented teaching mode, and teachers and students become the main body of teaching activities. In the class, teacher should integrate the teaching content actively into students, and guide the students to actively participate in all kinds of classroom activities. So, students become instructors, organizers, helpers and supervisors of the students' classroom learning activities. There are many ways of interaction between teachers and students, such as question\& answers, group discussion, pair work, role-play, reading out, class exercise -drills \& practice), delivering speeches, feed-backs, presentation and other ways to interact. In this way, teacher can create an active classroom atmosphere, stimulate student interest, and achieve good teaching effect. 


\subsection{After Class, Teacher Can Use Network to Layout Various Forms of Homework to Enable Students to Construct and Display Knowledge.}

For example, teacher can ask students to have dubbing practice for network resources, give video shots to a given topic, find your favorite songs and imitate singing, hold English speaking competition regularly, do role-play. Meanwhile teacher can encourage students upload the corresponding homework to the class communication group on the Internet. Students and teachers can interact and learn through network resources, such as advanced network system, teaching software, teaching website and other network resources. Students can also use mobile phones, websites, iPad, and electronic reading room, language laboratory, self-learning center, multimedia classroom to learn by themselves.

The students' construction of knowledge depends not only on their own knowledge level and experience, but also on the common discussion and understanding of the problems among their peers to some extent. Network-based interactive teaching mode can not only satisfy learners' personalized learning needs, but also emphasize cooperative learning and collective learning among learners. The interaction between students and students requires the combination of cooperative learning among students, collective learning and personalized learning of students. Students or peers can learn from each other and help each other in the network environment. They can share their learning experiences of a certain learning task, communicate with each other, cooperate with each other to complete the learning task, learn from each other, make up for each other, solve problems together, and achieve common progress and improvement.

\subsection{The Rich and Colorful Extracurricular Activities}

The extracurricular activities are the effective extension of College English teaching activities. It can create good learning environment for students and it is also a good mode of students' interaction. Our school offers students English clubs, English corner, English radio stations, etc.to provide students with a platform to express their thoughts and feelings in English.

Speeches contests, oral English competitions, English knowledge competitions, and English writing competitions and English talent show will enable students to show their talents in English, exercise their practical English skills and mine their learning potential, thereby enhancing their learning motivation and stimulating their learning and great passion for English learning. These communication platforms and competitions not only enrich students' amateur cultural life, but also improve their Language skills and level, which has achieved the socialization of students' interaction and interaction in English teaching.

\subsection{A Network-Based Timely Evaluation Mode Can Promote the Realization of Teaching \\ Effect.}

Traditional evaluation often focuses on teacher's individual correcting of students' homework. After the implementation of the new homework assignment, the evaluation mode of teachers is also very diverse. In the network student exchange group, the teacher not only can score the students' individual performance, but also the group display performance immediately. Besides, group-group score can also be achieved. The teacher's review can be displayed not only by the score, but also in the form of cute network expressions and voice. This will greatly increase the students' enthusiasm for learning and they will work harder to use the constructed knowledge. It forms a virtuous circle and promotes the realization of teaching effect.

In addition, if the homework is from the corresponding English platform or some English soft-wares, the student can get the immediate feedback of the software or system at a faster first moment. So, they can see the answers' analysis quickly, and find their mistakes, and correct them in time. For the first moment, they will memorize the correct knowledge again, and continue to strengthen it through the following exercises so as to achieve the correct reserve of knowledge in the brain. 


\section{Conclusion}

Constructivism learning theory emphasizes that students can solve problems they encountered in their learning process through their active participation. The learning and teaching concept he advocated adapted to the need of creative people of the current society- a society filled with information technology and popularization of network. The constructivism learning theory has a great influence on the English teaching. It has provided a good way of thinking for the teaching of English based on the network.

\section{References}

[1]. Chen Yuqing. Constructivism theory and learner's autonomous learning ability [J]. Journal of Chongqing Institute of Technology, 2005 (2), p. 165.

[2]. Qian Xiaohua. English autonomous learning ability in Internet plus era[J]. Teacher's Expo, 2016 (6), p. 4-6.

[3]. Leng Guohua, Xu Yi, Shu Suoping. The construction and teaching application of network course supported by new constructivism theory [J]. Zhenjiang Journal of higher education, 2012,25 (2), p. 70-73.

[4]. Hou Minji. Talking about the reform of College English teaching from the perspective of constructivism. [J]. Journal of Jishou University, 2006, p. 27.

[5]. Wang Zhuli. The new constructivism learning theory in Network Era [J]. Journal of Distance Education, 2011 (2), p. 12-13.

[6]. Huang Ying. Micro-class -- a new constructivism teaching method in the Internet age[J]. Journal of Nanjing Institute of Industry Technology, 2013, (09), p. 184-185.

[7]. Gao Wen, Xu Binyan, Wu Gang. Constructivism Education Research [M]. Beijing: Educational Science Press, 2008, p. 56.

[8]. Fan Wenhui. Practice research of web based interactive teaching mode in Higher Vocational Education [J]. Journal of Guangdong Communication Polytechnic.2016 (12), P. 82-85. 